\title{
共通鍵暗号の発展 一MISTY1をめぐる創造と破壊
}

Evolution of Symmetric-Key Cryptosystems -Creation and destruction over MISTY1

藤堂洋介 Yosuke TODO

アブストラクト 大量の情報を取り扱う昨今, 暗号は必要不可欠な技術となった. とりわけ高速に暗号化及び復号が可能な共通 鍵暗号は幅広く利用されている. 一方で共通鍵暗号の安全性は非常に発見的な方法で保たれている.すなわち多くの暗号学 者が様々な角度から暗号解析を試み，誰も解読できなかったならば安全という考え方だ．これは逆を言えば，安全と信じら れていた暗号がある日突然解読されることもあり得ることを意味する．本稿では共通鍵暗号の発展の裏にある創造と破壊の 歴史を紹介するとともに，ブロック暗号『MISTY1』に対する世界初の理論解読法で利用された新技術を概観する。

キーワード 暗号理論, 共通鍵暗号, ブロック暗号, 暗号解析, Integral 攻撃, Division Property

Abstract Cryptosystems are one of the most important tools for information security, and symmetric-key ciphers are widely used. Cryptographers have developed and applied various cryptanalysis techniques to guarantee security. If no one can attack a symmetric-key cipher, the cipher is regarded as secure. In other words, it is possible that a symmetric-key cipher will suddenly be broken. In this article, we introduce the history of the creation and destruction of symmetric-key ciphers. We also review a new cryptanalytic tool that was used to theoretically break the symmetric-key cipher MISTY1.

Key words Cryptology, Symmetric-key cipher, Block cipher, Cryptanalysis, Integral attack, Division property

\section{1. はじめに}

重要な情報を取り扱う昨今，暗号は必要不可欠な技術となっ た . 暗号理論では一般に暗号化されるメッセージを平文 , 復号 されるメッセージを暗号文と呼ぶ . 暗号には大きく分けて公開 鍵暗号と共通鍵暗号がある.公開鍵暗号では始め復号側が鍵生 成を実行し秘密鍵と公開鍵を生成する.平文は公開鍵を利用し て暗号化され，この暗号文は対応する秘密鍵を用いてのみ復号 できる . 公開鍵は光の名のとおり一般に公開可能であり，公開 鍵暗号を利用することで暗号化側と復号側が事前に鍵共有を行 うことなく秘匿情報を共有できる．公開鍵暗号では高い機能性 を実現するために高度な数学の技術が利用され，暗号化や復号 の処理において数学的演算を必要とする.このような演算は少 量の情報の処理では問題にならないが, 大容量の情報の処理で は多くの時間を要してしまう．したがって大容量の情報を取り 扱う際には, 公開鍵暗号よりも共通鍵暗号が利用されている.

共通鍵暗号の歴史は非常に古く紀元前まで遡る . 例として古 代ローマの政治家ガイウス・ユリウス・カエサルによって使わ れたとされるシーザ一暗号は有名である .また推理小説などに 登場する暗号も共通鍵暗号と言える．暗号学者は現代共通鍵暗

\footnotetext{
藤堂洋介 学生員 日本電信電話株式会社 NTT セキュアプラットフォーム研究所 E-mail todo.yosuke@lab.ntt.co.jp

Yosuke TODO, Student Member (NTT Secure Platform Laboratories, NIPPON TELEGRAPH AND TELEPHONE CORPORATION, Musashino-shi, 180-8585 Japan).

電子情報通信学会 基礎・境界ソサイエティ

Fundamentals Review Vol.10 No.1 pp.23-33 2016 年 7 月 (C)電子情報通信学会 2016
}

号と区別してこれらの暗号を古典暗号と呼ぶ . 古典暗号と現代 暗号の大きな違いは暗号化及び復号のための計算法 (アルゴリズ ム) を公開してよいか否かである.多くの古典暗号はアルゴリズ ムが公開されると安全性を維持できない，一方，現代暗号はア ルゴリズムに入力される鍵のみを秘匿しアルゴリズム光のもの は公開する . このようにすることでアルゴリズムの安全性を広 く議論できるようになり, 学問としての暗号研究が発展した .

\section{1 創造と破壊による発展}

かつて暗号は各国により最重要機密として管理されていた .し たがって暗号の歴史は非常に古いが, 学問としての暗号は現代 暗号以降に始まる .

現代共通鍵暗号は 1977 年に制定された旧米国政府標準暗号 Data Encryption Standard (DES) から始まる ${ }^{(1)}$. 以降, 共通 鍵暗号は創造と破壊を繰り返しながら発展した . 暗号学者は時 に創造主となり新しい暗号を設計し，時に破壊者となって既存 暗号を破壊する、暗号学者による破壊は安全な暗号を設計する ための設計理論に昇華され，更に優れた暗号の設計へと繋がる . この典型例として差分攻撃 ${ }^{(2)}$ と線形攻撃 ${ }^{(3)}$ による創造と破壊が ある. 差分攻撃と線形攻撃は共通鍵暗号の二大攻撃法として知 られ，これらの攻撃により DES は解読 (注1) された (3),(4). 光

(注1) : 暗号学者は秘密鍵を利用して暗号文から平文を得ることを復号と呼び解読と は呼ばない、解読とは秘密鍵を利用せずに暗号文から平文を得ること，及び末知の秘 密鍵を得ることを指す．また，ここで言う解読は鍵の全数探索よりも効率良く秘密鍵 及び平文が暴けることを意味し, 必ずしも現実的な環境て解読できるとは限らないこ とに注意されたい 
の後, 二大攻撃法に関する理論研究が進み ${ }^{(5)}$,(6), 1997 年に線 形攻撃の提案者である松井は二大攻撃法に対する安全性を証明 したブロック暗号として MISTY1 を提案した ${ }^{(7)}$.

\section{2 MISTY1 の解読}

二大攻撃法に対して安全なブロック暗号が提案される中，これ らを解読できる新しい暗号解読技術の研究が進んだ .しかしな がら，これらの解読技術は MISTY1 を解読するには至らず，約 20 年間谷の安全性は維持された . CRYPTO 2015 で MISTY1 はついに解読されることになる ${ }^{(8)}$. 利用されたのは Integral 攻 撃 (9) と呼ばれる 2002 年に提案された攻撃であり，特段新しい概 念の解読技術が発見されたわけではなかった . 乥れでは，なぜ今 更になって MISTY1 が解読されたのだろうか? これは Integral 攻撃の性能を最大限に引き出す術が知られていなかったからに ほかならない. MISTY1 の解読に先立って提案された Division Property ${ }^{(10)}$ と呼ばれる新技術は Integral 攻撃の性能を大幅に 引き上げ，これが MISTY1 解読へのブレークスルーとなった .

\section{2. ブロック暗号とその作り方}

\section{1 共通鍵暗号とブロック暗号}

共通鍵暗号の目的は共有した鍵を用いて平文・暗号文を高速 に暗号化・復号することにある . 共通鍵暗号は共通鍵暗号プリ ミティブを用いて構成され，ブロック暗号は最も一般的な共通 鍵暗号プリミティブである .

定義 1 (ブロック暗号). 固定長の平文と固定長の鍵を入力とし 固定長の暗号文を生成する関数 .

図 1 にブロック暗号を示す .ここで $n$ ビット平文と $k$ ビット 秘密鍵がブロック暗号の入力であり，出力は $n$ ビット暗号文で ある.このとき，このブロック暗号は $k$ ビット安全な $n$ ビット ブロック暗号と呼ばれる

ブロック暗号単体では共通鍵暗号として不十分である．なぜ ならブロック暗号は任意長の入出力を受け付けないためだ . 光 こでブロック暗号の使い方を定める暗号利用モードという技術 を用いて任意長の入出力に対応する .このとき暗号利用モード ではブロック暗号が安全ならば安全という安全性証明を付加す ることが一般的である．暗号利用モードもまた共通鍵暗号研究 における重要な研究分野の一つであるが，本稿では特にブロッ ク暗号に注目する。

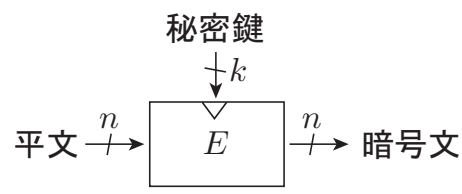

図 1 ブロック暗号

\section{2 ブロック暗号に求められる安全性}

ブロック暗号の構造は二入力一出力関数という非常に単純な ものであるが, 弚の求められる安全性要件は非常に厳しい.こ れはブロック暗号が樣々な暗号技術の構成要素であり，ブロック 暗号をどのように利用したとしても問題が生じないようにする ためである . 以下にブロック暗号を解析する上で一般的な攻撃 者の仮定を挙げる．

暗号文単独攻撃 攻撃者は複数の暗号文を観測し, 平文の統計 情報などを用いた上で，対応する平文または秘密鍵を解読する． 既知平文攻撃 攻撃者は複数の平文と暗号文のペアを観測し，秘 密鍵を解読する。

選択平文攻撃 攻撃者は任意に平文を選択し，対応する暗号文 を得られる .このように生成される平文と暗号文のペアを観測 し，秘密鍵を解読する．

少なくとも暗号文単独攻撃に対して安全でなければならないこ とを疑う者はいないだろう．暗号学者はブロック暗号のあらゆ る利用を想定し，更に既知平文攻撃や選択平文攻撃に対しても 安全であることを求めている.上述の攻撃は単一鍵攻撃 (一つの 秘密鍵を用いて生成された平文や暗号文を観測し光の秘密鍵を 解読する攻撃) と呼ばれる. 現在では関連鍵攻撃 (11)や既知鍵攻 撃(12)など , ブロック暗号に求められる安全性要件は日に日に 高まっている.

ブロック暗号が解読されたとはどういうことを意味するのだ ろうか? 暗号学者の言う “解読” と一般的な解読には大きなかい 離があることに注意されたい . 例として $k$ ビット安全なブロッ ク暗号を考える.攻撃者は $2^{k}$ 通りの秘密鍵を網羅的に評価する ことで, 必ず秘密鍵の解読が可能である. これは総当たり攻撃 (ブルートフォース攻撃) と呼ばれ，この計算量は $2^{k}$ である.暗 号学者の言う解読とはブルートフォース攻撃よりも少ない計算 量で解読できることを指す . 現在では $k=128$ であるブロック 暗号か瀕用されているが, この場合 $2^{128}$ 未満の計算量で秘密鍵 を解読できれば，暗号学者は “ブロック暗号は解読された” と言 う. 現在の一般的なコンピュータが計算できる計算量は $2^{45}$ 程 度であり，これは仮にスーパコンピュータを利用したとしても $2^{65}$ 程度である.したがって暗号学者による解読は直ちに実利 用に影響を与えない.だからと言って，暗号学者による解読は 無視されてはいけない.なぜなら暗号のマイグレーションには 多くの時間を要するためだ . 暗号学者により解読されたブロッ ク暗号は, 攻撃が洗練されることで解読に要する計算量が小さ くなり, 将来的には実利用においても解読される危険性が高く なる．すなわち暗号学者による解読は実利用に対する警鐘の第 一報として捉えるべきであり，これを目安に暗号のマイグレー ションを慎重に考え始めていくことが現実的な被害を防ぐこと に寄与する . 


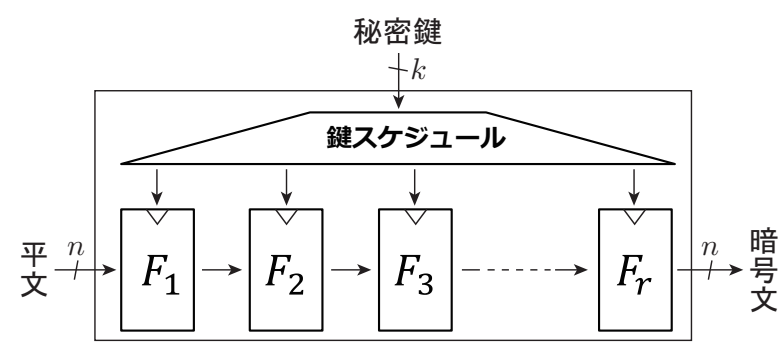

図 2 繰返し 型暗号

\section{3 ブロック暗号の作り方}

多くのブロック暗号は繰返し型構造を用いて設計される . 繰 返し型構造ではラウンド関数と呼ばれる小さなブロック暗号を 初めに設計する . ラウンド関数は効率良く計算できるが, 単体 ではブロック暗号としての安全性を備えていない . またラウン ド関数の鍵はラウンド鍵と呼ばれ, 秘密鍵を鍵スケジュールに 入力することで生成される．ブロック暗号は，このラウンド関 数を異なるラウンド鍵を用いながら任意回繰り返すことで構成 される.図 2 に $r$ 段ブロック暗号を示す . 繰返し回数 $r$ が大き くなればなるほどブロック暗号の安全性は向上するが計算効率 は悪化する．したがって十分な安全性を保持しながら繰返し回 数を最小化することを暗号設計者は求められる.

\section{4 MISTY1}

MISTY1 は 128 ビット安全な 64 ビットブロック暗号であり 推奨パラメータは 8 段 FL5 層である ${ }^{(7)}$. MISTY1 は樣々な機 関で標準化されており，例として CRYPTREC の推奨候補暗号 リスト (13), ISO/IEC 18033-3 ${ }^{(14)}$, NESSIE 推奨暗号 ${ }^{(15)}$ に選 ばれている.また RFC $2994^{(16)}$ でも MISTY1 が記述されて いる . 本稿では MISTY1 解読の概要のみを示すため MISTY1 の詳細な仕樣を解説しない. 詳細な仕樣に関しては提案論文を 参照されたい(7).

\section{3. 現代共通鍵暗号の歩み}

暗号は人の手によって造られ，人の造りし物は得てして欠陥 を持つ. 人が暗号を創造し, その後, 人の手によって破壊され， この破壊がもたらした新たな知識を持って新たな暗号を創造す る.共通鍵暗号は創造と破壊を繰り返しながら発展した . 図 3 に大まかな現代共通鍵暗号の歴史を整理した .

\section{1 現代共通鍵暗号の夜明け}

現代共通鍵暗号は旧米国政府標準暗号 Data Encryption Standard (DES) から始まる(1). DES は IBM か設計し, 1977 年に FIPS PUB46 として公表された . また, NTT はマイクロプロ セッサで高速に動作し，DES の代替となることを目的に FEAL を 1987 年に提案した ${ }^{(17)}$. 当時，共通鍵暗号に対する攻撃法は ほとんど公知になっていなかった . したがって当時の暗号の安 全性は設計者の経験と直感に委ねられていた .

\section{2 二大攻撃法による破壊}

DES や FEAL が共通鍵暗号研究にもたらした貢献は非常に 大きい .これらの暗号に対してどれだけ強力な攻撃法であるか がベンチマークとなり, 以降, 暗号解析に関する研究が盛んに行 われた . 光のような中で発見された暗号解析手法が Eli Biham と Adi Shamir による差分攻撃 ${ }^{(2)}$ と松井による線形攻撃 ${ }^{(3)}$ で ある. 差分攻撃と線形攻撃は光の汎用性の高さから共通鍵暗号 に対する二大攻撃法として知られている．FEAL 設計者にとつ て二大攻撃法は未知の技術であり, 結果として FEAL は二大攻 撃法によって解読された (18),(19). DES 設計者は差分攻撃を独 自に発見しており，DES は差分攻撃に対して比較的安全になる よう設計されていた．しかしながら，より効率の良い差分攻撃 の発見 ${ }^{(4)}$ や線形攻撃の発見により, 結果として DES もまた二 大攻撃法によって解読された .

\section{3 二大攻撃法がもたらした新たな創造と破壊}

1990 年代中盤に入り暗号学者の新たなモチベーションは二 大攻撃法に対して安全な暗号を設計することへ移った . 差分攻 撃と線形攻撃の本質は何なのかが盛んに研究され，これらの解 析に対して安全であることを保証できる設計理論も提案され た(5)，(6). 光のような中で設計された暗号の一つが MISTY1で ある ${ }^{(7)}$. MISTY1 の提案者は線形攻撃を発見した松井であり， その松井が二大攻撃法に対して安全であることを理論的に保証し た暗号ということで, MISTY1は世界中の暗号学者の注目を集 めた . 更に 1990 年代後半にはブルートフォース攻撃でも DES が解読され始め, アメリカ国立標準技術研究所 (NIST) は新た な共通鍵暗号の公募を開始した .これは AES コンテストと呼ば れ，現在世界中で最も利用されているブロック暗号 Advanced Encryption Standard (AES) ${ }^{(20)}$ か誕生するに至ったコンテス トである . AES に選ばれた Rijndael もまた二大攻撃法に対し て十分に安全であることが保証されている(21).

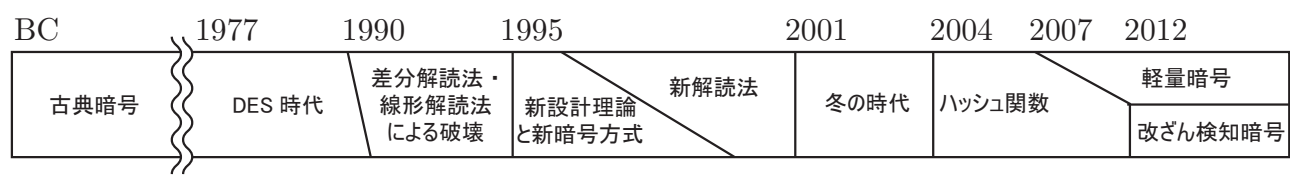

図 3 現代共通鍵暗号の歩み 
差分攻撃や線形攻撃では新たな暗号を解読することはできな い. 光こて暗号学者たちの新たなモチベーションはこれらの暗号 を解読できる新たな攻撃法の発見へと移った . 高階差分攻撃 ${ }^{(22)}$ 不能差分攻撃 ${ }^{(23)}$, Integral 攻撃 (9), 無相関攻撃 (24)などが兴の 例である . 差分攻撃や線形攻撃を発展させた攻撃法から全く新し い観点の攻撃法まで，多岐にわたる新しい政撃法が提案された。

\section{4 ブロック暗号 冬の時代}

確かに多くの攻撃法が提案され, 光れらは二大攻撃法よりも 強力な攻撃法になり得た．しかしながら暗号学者の努力もむな しく，これらの新しい手法は MISTY1 をはじめ数多くの著名暗 号を解読するに至らなかった . 以降，ブロック暗号に関する設 計や解読の研究は途切れずに提案されるが, AES 選定以前と比 較すると, 弚の量は激減した .

ブロック暗号の研究が一段落ついたことから，共通鍵暗号に 関する新たな研究が起こった . 例として暗号利用モードに関す る研究がある.AES が標準化されることから，谷の利用方法を 定める暗号利用モードに注目が集まり，多くの研究成果か報告さ

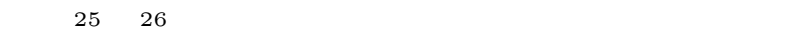
れるストリーム暗号の研究が進んだ . ヨーロッパの ECRYPT は eSTREAM プロジェクトにてストリーム暗号の設計コンテ ストを進めた . ストリーム暗号に関する研究は以前の本誌で詳 しく取り上げられているため, 弚ちらを参照されたい(27).

\section{5 ハッシュ 関数時代}

2004 年の CRYPTO Rump Session で提案されたハッシュ関 数の衝突攻撃に関する発表は共通鍵暗号業界に大きな衝撃を与 えた ${ }^{(28)}$. この報告以降, ハッシュ関数の研究が共通鍵暗号研究 のメインストリームとなり， NIST もまた 2007 年から 2012 年 にかけてハッシュ関数設計コンテスト (SHA-3 コンテスト) を 進めた . ハッシュ関数に関する研究も以前の本誌で詳しく取り 上げられているため, 弚ちらを参照されたい(29).

\section{6 目的特化型時代}

ここ数年の共通鍵暗号研究を俯瞰してみると，時代は目的特 化型へと移ってきたように思える .この流れは 2007 年に提案さ れた軽量ブロック暗号 PRESENT に始まる ${ }^{(30)}$. 汎用的な利用 を想定したブロック暗号ではなく，今後の IoT 社会を見据え軽 量実装に特化したブロック暗号が多数提案された ${ }^{(31) \sim(35)}$.

軽量暗号の他にも改ざん検知暗号 (Authenticated Encryption) の研究も盛んに行われるようになった ${ }^{(36) \sim(40)}$. 通常の 共通鍵暗号は暗号化及び復号機能を備えるが , メッセージの改 ざんを検知することができない．改ざん検知暗号は暗号として の通常の機能にプラスしてメッセージの改ざんを検知する機能 を有する . 改ざん検知暗号に関しては現在 CAESAR コンテス ト(41)が進められている。
4. MISTY1 に対する Integral 攻撃と 高階差分攻撃

MISTY1 の解読には二大攻撃法以外の方法が必要不可欠であ り, 前世紀末から数多くの新しい方法が提案され, 光れらの方 法が MISTY1 に適用されてきた．にもかかわらず, MISTY1 は光の安全性を保持し続けた .

本章では MISTY1 に対する強力な攻撃法として知られてい た Integral 攻撃 ${ }^{(9)}$ と高階差分攻撃 ${ }^{(22)}$ を光れぞれ解説する.両 攻撃は全く異なる定式化がなされているにもかかわらず, 多く の場合で同一視される.恐らく共通鍵暗号を専門とする暗号学 者でさえ両攻撃の違いを正確に把握している者は少ない．本章 では両者の攻撃を比較し，Integral 攻撃と高階差分攻撃の違い に関して解説する。

\section{1 Integral 攻撃}

Integral 攻撃という名前が提案されたのは 2002 年だが , 同樣 の原理を用いた攻撃法は 1997 年に提案された ${ }^{(42)}$. これは解析 論文ではなくSQUARE と呼ばれるブロック暗号の提案論文だっ た.SQUARE は後に AES となる Rijndael の基となったブロッ ク暗号であり, ブロック暗号設計においても非常に重要な暗号 の一つである .

Integral 攻撃は初め SQUARE に対する専用解析手法として提 案された . 専用解析手法として示されたにもかかわらず，この解 析アイデアはブロック暗号に対して広く適用可能であり，以降， 多くの解析論文で利用された ${ }^{(43) \sim(47)}$. しかしながら SQUARE 提案論文では攻撃名が定められていなかったこと，また攻撃の フォーマライズが不十分だったことから, 追従研究の攻撃名は多 岐に渡った . 最もよく使われた名前は Square 攻撃 (43) (45)で

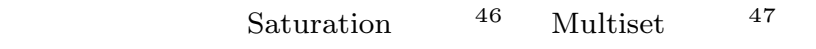
どの名称が利用された . 2002 年, Knudsen と Wagner は一連 の攻撃を定式化し，これを Integral 攻撃と冠した ${ }^{(9)}$. 共通鍵暗 号を専門とする暗号学者ですら困惑するのだが, Square 攻撃， Saturation 攻撃, Multiset 攻撃, Integral 攻撃は今では同一の 攻撃法とみなす方が自然である .

図 4 に Integral 攻撃のアウトラインを示す . 攻撃者は初めに Integral 特性の探索を行う. Integral 特性とは特定の平文集合 に属する全ての平文を複数段暗号化した中間状態の (一部の) 和 が全ての鍵に対して0になる特性を指す．すなわち全てのとり 得る $r k$ において

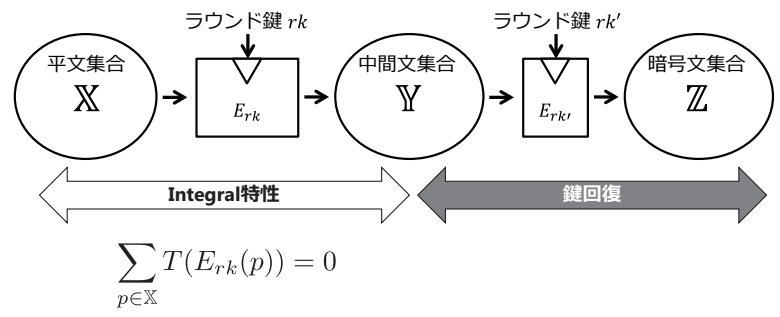

図 4 Integral 攻撃の概要 


$$
\sum_{p \in \mathbb{X}} T\left(E_{r k}(p)\right)=0
$$

を満足する平文集合 $\mathbb{X}$ を探索する .ここで $T$ は観測関数であり， 通常は $n$ ビットから任意のビットを切り出す関数などが利用さ れる．理想的なブロック暗号において式 (1) を満足する確率は 非常に小さい，すなわち攻撃者は Integral 特性を構築すること で, 理想的なブロック暗号と実際の暗号を識別する Integral 識 別子を構成できる.

実際の暗号解析のシナリオでは鍵回復を Integral 特性に付 加することで Integral 攻撃を実行する．ブロック暗号が $r$ 段 Integral 特性を持つと仮定し， $(r+s)$ 段ブロック暗号の解析を 試みる. 攻撃者は最終 $s$ 段で使われるラウンド鍵を推測し $r$ 段 中間状態の和を評価する .もし推測したラウンド鍵が正しい場 合，式 (1) は必ず満たされる．したがって式 (1) を満たさない とき，推測したラウンド鍵は誤っていることが分かる．この手 順を繰り返すことで, 攻撃者は最終 $s$ 段で使われたラウンド鍵 を正しく解読することができ，最終的にこれらの情報から秘密 鍵を解読する。

\section{2 高階差分攻撃}

Integral 攻撃を語る上で外せないもう一つの重要な攻撃法に 高階差分攻撃がある ${ }^{(22)}$. 高階差分攻撃が提案されたのは 1994 年であり, Square 攻撃からは 3 年, Integral 攻撃からは実に 8 年も前である . 高階差分攻撃の基本的な考え方は一種の差分攻 撃の一般化である . ある $n$ ビットブロック暗号 $E_{K}$ に対して差 分攻撃は

$$
\Delta_{\alpha} E_{K}(x)=E_{K}(x+\alpha)-E_{K}(x)
$$

を考え， $\alpha$ と $\Delta_{\alpha} E_{K}(x)$ の関係性を解析して秘密鍵 $K$ を解読 する . これに対して高階差分攻撃は

$$
\Delta_{\alpha_{1}, \alpha_{2}, \ldots, \alpha_{i}}^{(i)} E_{K}(x)=\Delta_{\alpha_{i}}\left(\Delta_{\alpha_{1}, \alpha_{2}, \ldots, \alpha_{i-1}}^{(i-1)} E_{K}(x)\right)
$$

を考え， $\left(\alpha_{1}, \alpha_{2}, \ldots, \alpha_{i}\right)$ と $\Delta_{\alpha_{1}, \alpha_{2}, \ldots, \alpha_{i}}^{(i)} E_{K}(x)$ の関係性を解 析して秘密鍵 $K$ を解読する .これは $i$ 階差分と呼ばれ，例えば 2 階差分は

$$
\begin{aligned}
\Delta_{\alpha_{1}, \alpha_{2}}^{(2)} E_{K}(x)= & \Delta_{\alpha_{2}}\left(E_{K}\left(x+\alpha_{1}\right)-E_{K}(x)\right) \\
= & E_{K}\left(x+\alpha_{1}+\alpha_{2}\right)-E_{K}\left(x+\alpha_{2}\right) \\
& -E_{K}\left(x+\alpha_{1}\right)+E_{K}(x)
\end{aligned}
$$

となる . Lai は高階差分を取ることで暗号の複雑さ指標の一つで ある次数を減少させることができることを指摘した．より具体 的には次数が $d$ である暗号において,$d+1$ 階差分は 0 となるこ とを指摘した . これは $k$ ビット安全なブロック暗号は, 少なく とも次数が $k-1$ 以上にならなければならないことを示唆して いる.また 1994 年，Knudsen は高階差分攻撃を Toy Cipher (理論を整理するために導入される簡易なブロック暗号のこと) に適用した結果を報告した ${ }^{(48)}$.

\section{3 Integral 攻撃と高階差分攻撃は同じ?}

Integral 攻撃と高階差分攻撃は明らかに異なる定義を持つ.し かしながら，この差を明確に区別している暗号学者は恐らく少 ない．これはブロック暗号の構造の特殊性に起因する．ブロッ ク暗号は $n$ ビット入力 $n$ ビット出力で計算される都合上, 各演 算は論理演算で定義されることが多い .このとき Integral 攻撃 の加算や高階差分攻撃の差分は共に排他的論理和 $(\oplus)$ となる . 例として 2 階差分は

$$
\begin{aligned}
\Delta_{\alpha_{1}, \alpha_{2}}^{(2)} E_{K}(x)= & E_{K}\left(x \oplus \alpha_{1} \oplus \alpha_{2}\right) \oplus E_{K}\left(x \oplus \alpha_{1}\right) \\
& \oplus E_{K}\left(x \oplus \alpha_{2}\right) \oplus E_{K}(x) \\
= & \bigoplus_{p \in V\left[\alpha_{1}, \alpha_{2}\right]} E_{K}(p)
\end{aligned}
$$

と変形でき，ここで $V\left[\alpha_{1}, \alpha_{2}\right]$ は $\left(\alpha_{1}, \alpha_{2}\right)$ を線形独立な $n$ 次元 ベクトルとし，これによって張られる部分空間である . すなわ ち排他的論理和における Integral 攻撃と一致する .

高階差分攻撃は光の特徵上, 線形独立なべクトルで張られる 部分空間をメッセージ集合として利用する . 一方で Integral 攻 撃は任意のメッセージ集合を利用できる．すなわち排他的論理 和における Integral 攻撃は高階差分攻撃よりも広い概念の攻撃 とみなせる . しかしながらブロック暗号の構成要素の入出力も また計算効率の向上のためビット表現されることから，既存の ほぼ全ての Integral 攻撃は結局のところ線形独立なべクトルで 張られる部分空間をメッセージ集合として利用する．すなわち， 両攻撃を区別していた要素は一般的なブロック暗号に適用した 途端消滅し，結局のところ Integral 攻撃は高階差分攻撃と同一 の攻撃となる.

\section{4 どのようにして Integral 特性を発見するのか?}

Integral 攻撃にしろ, 高階差分攻撃にしろ, 課題はいかにし て Integral 特性を探索するかである.したがって，Integral 特 性をどのように発見するかに着目し，4.4.1 の方法の場合は Integral 攻撃, 4.4.2 の方法の場合は高階差分攻撃, の名前を 使う研究者が多い.

\subsubsection{Integral Propertyを用いた Integral 特性探索}

Knudsen と Wagner は Integral 攻撃の提案論文にて, Integral 特性を探索する汎用的な手法を示した ${ }^{(9)}$. これは Integral

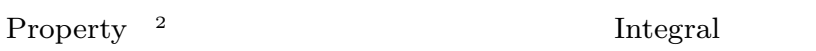
探索する上で最も利用される手法である(33)，(45),(49),(50). こ の手法では入力の部分集合に対して以下に示す四つの Integral Property を付与し，兴の伝搬を評価する．

- $\operatorname{ALL}(\mathcal{A})$ : 全ての值が同一回出現する集合

- $\operatorname{BALANCE}(\mathcal{B})$ : 全ての值の総和が 0 になる集合

(注2)：Integral Property と Integral 特性は異なることに注意されたい . Integral 特性は暗号全体に対する性質であり, 英語では Integral Characteristic と表記される . 


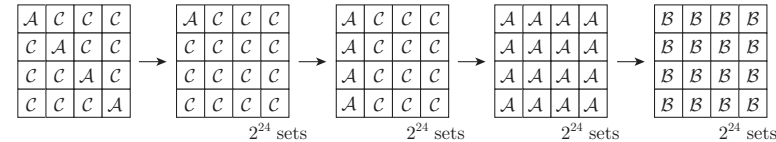

図 54 段 AES の Integral 特性

- $\operatorname{CONSTANT}(\mathcal{C})$ : 全ての值が固定となる集合

- $\operatorname{UNKNOWN}(\mathcal{U})$ : ランダムと識別不可能な集合

Knudsen と Wagner は Integral Property の伝搬を用いて AES の 4 段 Integral 特性を示した ${ }^{(9)}$. 図 5 は光の Integral 特 性を示す. 始め攻撃者は対角成分を連結した 32 ビット值が $\mathcal{A}$ となるような $2^{32}$ 個の選択平文を用意する . 1 段暗号化した中 間状態は左上の 1 バイトが $\mathcal{A}$ となり残りが $\mathcal{C}$ となる集合が $2^{24}$ セット作られる状態となる．2 段暗号化した中間状態は左 1 列 の各バイトが $\mathcal{A}$ となり残りが $\mathcal{C}$ となる集合が $2^{24}$ セット， 3 段 暗号化した中間状態は各バイトが $\mathcal{A}$ となる集合が $2^{24}$ セット作 られる状態となる. 結果として 4 段暗号化した中間状態の各バ イトは $\mathcal{B}$ となる .

\subsection{2 次数見積りによる Integral 特性}

Integral 特性を探索するもう一つの手法は次数の見積りであ る(22)，(48).この手法を用いた解析は Integral 攻撃というより は高階差分攻撃と呼ぶ方が自然である .

この手法の最大の課題は次数の上界を求めることが極めて難 しいことにある.文献 (51) では数式処理システム REDUCE を 用いて簡易版 MISTY1 ${ }^{(7)}$ の次数を見積もり光の 7 階差分特性 を発見した .この手法は正確な次数を見積もれる一方で階数の 高い高階差分特性を発見することは計算量的に困難である .

効率的に繰返し暗号の次数の上界を導出する手法は Canteaut らによって提案され ${ }^{(52)}$, この上界は後にBoura らによって改良 され $\mathrm{KECCAK}^{(53)}$ と Luffa ${ }^{(54)}$ の Integral 特性が示された ${ }^{(55)}$. しかしながら，この手法によって導出される上界は依然として 緩いものであり，多くの場合で Integral Property の伝搬特性 の方が優位な Integral 特性を発見する.

\section{5. なぜ MISTY1 は破られたのか?}

2015 年 , 20 年間解読されることがなかった MISTY1 がつい に解読された ${ }^{(8)}$. 解読に用いられたのは Integral 攻撃であり， 特段新しい政撃法というわけではなかった．弚れではなぜ，今 更になって MISTY1 が Integral 攻撃によって解読されたのだ ろうか? 弚れは従来の Integral 攻撃は, 弚の性能を最大限に 引き出せていなかったからにほかならない . MISTY1 の解読 に先立って提案された Division Property と呼ばれる新技術は Integral 攻撃の性能を大幅に引き出すことを可能にし(10), これ が MISTY1 解読へのブレークスルーとなった .

\section{1 MISTY1 は安全なはずだった？}

\subsubsection{Pre-MISTY}

MISTY1 の設計者である松井は MISTY1 の提案以前に俗に Pre-MISTY と呼ばれる暗号を提案している ${ }^{(6)}$. Pre-MISTY から MISTY1 への仕樣変更に際し，松井は次数が上昇しやす くなるような細工を加えている．松井は後に「次数が小さいの は明らかにぜい弱性を生む危険性があるため, 計算効率は劣化 するが安全性を考慮して変更した」と述べている.当時, 高階 差分攻撃は既知の技術だったとは言え, 光れほど強力な攻撃と いう認識はまだなかった .乥れにもかかわらず Pre-MISTY か ら仕樣変更を施したことは松井の設計センスのなせる技であり， これは MISTY 1 が 20 年間破られなかったことに大きく貢献し たと考えられる．

繰り返すが，結局のところ MISTY1 は Integral 攻撃により 解読されたのであり, 結果的には MISTY1での仕樣変更でも不 十分だったことになる．しかし，これには Integral 攻撃の本来 の性能を大幅に引き出すことを可能にした Division Property の発見が必要不可欠だった .

\section{1 .2 日進月歩な高階差分攻撃}

Division Property の発見以前からも MISTY1 に対する解析 のメインストリームは Integral 攻撃だった(注3) . MISTY1 と Integral 攻撃の歴史は 1999 年に始まる ${ }^{(51)}$.ここで田中らは数 式処理システム REDUCE を用いて MISTY1 の次数を厳密に 評価し，簡易版 3 段 MISTY1 の 7 階差分特性を発見した . こ の 7 階差分特性の代数的性質は Babbage ら ${ }^{(56)}$ 及び Canteaut ら ${ }^{(52)}$ によって关れ攵れ調査されている. 兴の後，7 階差分特 性を拡張することで 3 段 MISTY1 の 14 階差分特性が導出さ れ，5段 MISTY1 が解読された ${ }^{(57)}$. 更に 14 階差分特性を拡 張することで 4 段 MISTY1 の 46 階差分特性が導出され，6段 MISTY1 が解読された ${ }^{(58)}$. 後に, 46 階差分特性は 44 階差分 特性へと改良され(59), これにより攻撃段数は变わらないが, よ り効率良く攻撃を実行できるようになった . 2015 年に , Bar-On は 44 階差分特性を用いて 7 段 MISTY1 を解読できることを示 した ${ }^{(60)}$.

\subsection{MISTY1 を解読したブレークスルー技術}

MISTY1 の解読可能な段数は日進月歩に伸びてきた .しかし Bar-On による最新の結果 ${ }^{(60)}$ ではあらゆる既存技術が組み合 わさり, 今後, 攻撃に必要な計算量やメッセージ数を少なくす ることはできても，仕樣段数である 8 段を解読できるのは随分 先になるだろう，と思われていた . それれにもかかわらず 2015 年 に MISTY1 が突然解読されたのは Division Property の発見 があったからにほかならない . Division Property は Integral 特性を発見する新しい方法であり，MISTY1 を解読する際に用

(注3) : 最も基本的な Integral 特性が次数の見積りによるもののため多くは高階差 分攻撃の名を冠して提案されている。 


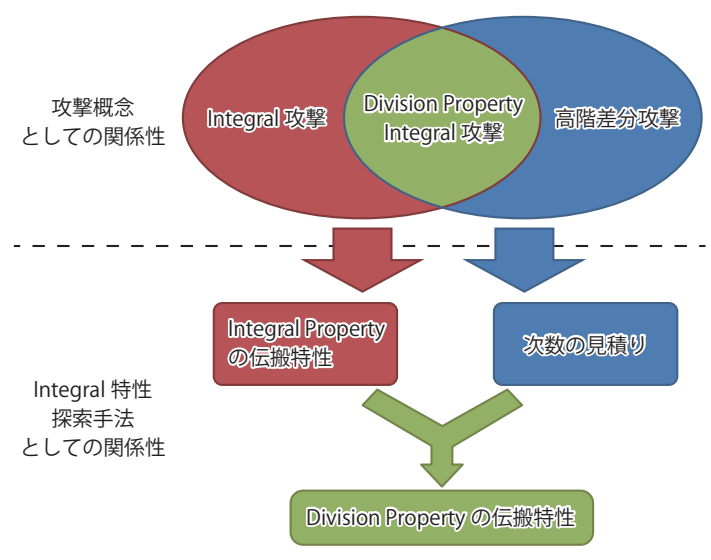

図 6 概念と手法の関係性

いられた Integral 特性は全ての既存研究が利用してきた特性と は全く異なる方法で導出されたものだった．

\subsection{1 発 想}

Division Property は “Integral 攻撃と高階差分攻撃は結局の ところ同じ攻撃法だ”という発想から始まっている．もちろん， 厳密なことを言えば両者の攻撃は異なる．しかし，多くの場合 は排他的論理和を，乥して線形独立なべクトルで張られる部分 空間をメッセージ集合として利用するため，両者の差は消失し ている．乥れにもかかわらず Integral Property の伝搬特性は 次数を直接的には利用していなかった . Division Property は Integral 攻撃と高階差分攻撃が重なる領域に注力し，4.4 で示 した二つの探索手法の長所を融合させたものである . 具体的に は 4.4.1 で示した Integral Property を次数も利用できるよう 一般化したものが Division Property である .

図 6 に従来の Integral 攻撃, 高階差分攻撃, 光して Division Property を用いた解析の関係性を整理した . 始めに攻撃概念と しての違いを整理すると，Division Property を用いた解析は Integral 攻撃と高階差分攻撃が重なる領域に特化している．す なわち Division Property を用いた解析は Integral 攻撃のサブ セットでもあり高階差分攻撃のサブセットでもある .これは攻 撃の概念としては Division Property を用いた解析は絶対に高 階差分攻撃や Integral 攻撃を上回ることができないことを意味 する .

5.2.2 なぜ Division Property は従来よりも優れているのか? 概念としては従来攻撃のサブセットであるにもかかわらず，な ぜ Division Property は従来よりも優れているのだろうか? 少 なくとも，Division Property を用いた解析は “完璧な高階差分 特性”と比較すると必ず劣る特性であり，㫕の性能が上回ること はあり得ない(注4)．重要なのは “完璧な高階差分特性”を発見す ることは, 現在の人類の知識と計算能力では不可能であること にある

数式処理システムを用いて次数の上界を正確に導出した場合，

(注4)：同樣の考察は金子によってなされており，ここで Division Property に より得られる最良の Integral 特性は高階差分特性に一致することか証明されてい $3^{(61)}$.

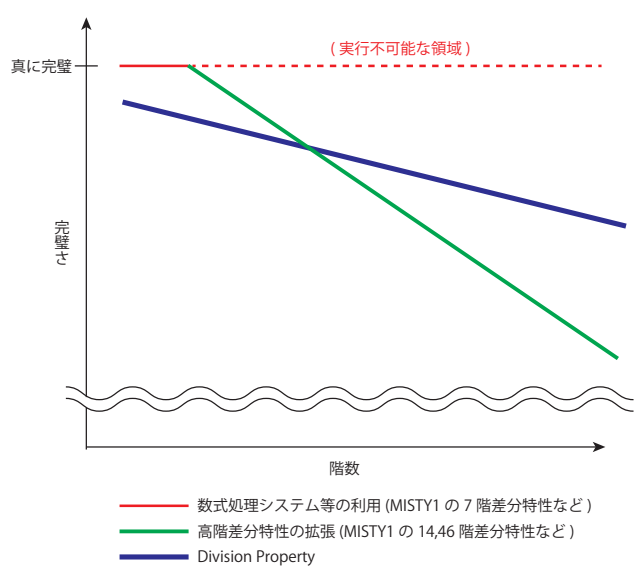

図 7 従来の高階差分特性と Division Property

その手法で発見された高階差分特性は “完璧な高階差分特性”で ある.しかしながら，結局のところ “完璧な高階差分特性”を発 見することは事実上不可能である. MISTY1 を例として考える . MISTY1 は始め 7 階差分特性を数式処理システムを用いて導出 している．したがって，この高階差分特性は “完璧”である．し かし, 数式処理システムでは階数の大きな高階差分特性は評価で きない．したがって，この “完璧な高階差分特性”を拡張するこ とで階数の大きな高階差分特性を構成してきた .この拡張は完 璧から程遠いものであり，結果的に攻撃に利用される高階差分特 性は “完璧”から程遠いものだった .一方でDivision Property は“完璧な高階差分特性”を発見できる保証はないが，光れに限 りなく近い特性を発見できる.更に数式処理システムと異なり， 階数が大きな範囲でも Division Property の伝搬特性は評価可 能である . 図 7 に従来の高階差分特性と Division Property に よる Integral 特性の “完璧さ” と階数の関係性を整理した . 数 式処理システムで計算が終了するような階数が小さな範囲では Division Property は従来手法よりも優れた手法ではない . しか しながら，実際のブロック暗号解析では階数が大きな Integral 特性のみを通常利用するため，多くの環境で Division Property は従来手法よりも優れた Integral 特性を発見する.

\subsubsection{Division Property の原理}

Division Property の原理を簡単に説明する . Division Property は Integral Property を次数が利用できるよう一般化した ものであるため, 初めに Integral Property の数学的特徵を再 整理する .

$\mathbb{X}$ を各要素が $n$ ビットである多重集合として $\mathbb{X}$ は Integral Property $\mathcal{A}$ を満足すると仮定する .すなわち $\mathbb{X}$ は $n$ ビットの

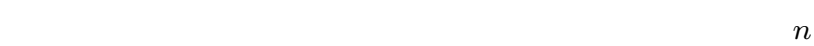
ビットから任意の 1 ビットを選択し $\mathbb{X}$ の全要素に対して選択し たビットの排他的論理和を考える .このとき $\mathbb{X}$ は $\mathcal{A}$ を満足す るため排他的論理和は必ず 0 となる．また $n$ ビットから任意の $n-1$ ビットを選択し $\mathbb{X}$ の全要素に対して選択されたビットの AND 值の排他的論理和を考える .このとき排他的論理和は同樣 に必ず 0 となる.最後に全 $n$ ビットを選択し $\mathbb{X}$ の全要素に対し て全ビットの AND 值の排他的論理和を考える . このとき排他 


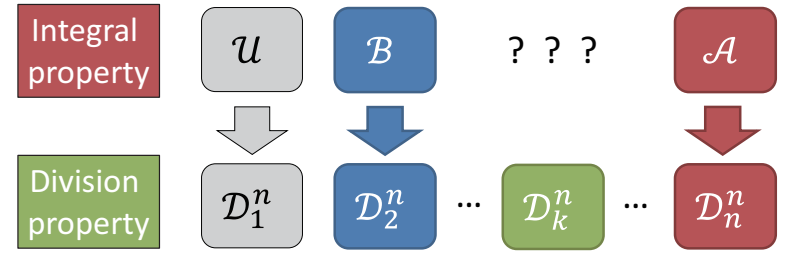

図 8 Division Property と Integral Property

的論理和が 0 になるか 1 になるかは不定となる(注5)．すなわち 初めに $n$ ビット値 $u$ において, 多重集合の全要素 $x \in \mathbb{X} に$ 対す る $\pi_{u}(x)=\prod_{i=1}^{n} x[i]^{u[i]}$ のパリティ $\left(\bigoplus_{x \in \mathbb{X}} \pi_{u}(x)\right)$ を計算す る.ここで $x[i]$ 及び $u[i]$ は $x$ 及び $u$ の $i$ 番目のビットを表す このときハミング重み $w(u)$ が $n$ 末満な場合パリティは even と なり， $w(u)$ が $n$ と一致する場合パリティは不定となる .

次に $\mathbb{X}$ は Integral Property $\mathcal{B}$ を満足すると仮定する . 初め に $n$ ビットから任意の 1 ビットを選択し $\mathbb{X}$ の全要素に対して 選択したビットの排他的論理和を考える .このとき $\mathbb{X}$ は $\mathcal{B} を$ 満 足するため排他的論理和は必ず 0 となる . 次に $n$ ビットから任 意の 2 ビットを選択し $\mathbb{X}$ の全要素に対して選択されたビットの AND 值の排他的論理和を考える .このとき $\mathbb{X}$ が $\mathcal{B}$ を持つとい う条件のみでは排他的論理和が 0 になるか 1 になるかは不定と なる.すなわち多重集合の全要素 $x \in \mathbb{X}$ に対して $\pi_{u}(x)$ のパリ ティ $\left(\bigoplus_{x \in \mathbb{X}} \pi_{u}(x)\right)$ は $w(u)<2$ を満足する全ての $u$ におい て even であり, $w(u) \geqq 2$ を満足する全ての $u$ において不定と なる。

$\mathcal{A}$ と $\mathcal{B}$ の再定義では同一の表記法が用いられている . 具体的 には全ての $u$ において多重集合の全要素 $x \in \mathbb{X}$ に対する $\pi_{u}(x)$ のパリティを計算し，次に $w(u)$ に着目することでパリティが even となる $u$ の部分集合と不定となる $u$ の部分集合に分割す る .これらを一般化することで Division Property は以下のよ うに定義される。

定義 2 (Division Property). $\mathbb{X}$ を各要素が $n$ ビットの值を持 つ多重集合とする．また $k$ は 0 から $n$ までの值を取るとする． 多重集合 $\mathbb{X}$ が Division Property $\mathcal{D}_{k}^{n}$ を持つとは下記条件を満 足することをいう．

$$
\bigoplus_{x \in \mathbb{X}} \pi_{u}(x)= \begin{cases}\text { unknown } & \text { if } \mathrm{w}(\mathrm{u}) \geqq \mathrm{k}, \\ 0 & \text { otherwise. }\end{cases}
$$

Division Property は $\bigoplus_{x \in \mathbb{X}} \pi_{u}(x)$ が不定か 0 かに注目して $u$ の集合を分割することで定義される . Division Property は Integral Property を細分化した形になっている.图8にDivision Property と Integral Property の関係性を示す . Integral Property $の \mathcal{A}, \mathcal{B}, \mathcal{U}$ は兰れ羿れ $\mathcal{D}_{n}^{n}, \mathcal{D}_{2}^{n}, \mathcal{D}_{1}^{n}$ に対応する Division Property では新たに $\mathcal{D}_{3}^{n}$ から $\mathcal{D}_{n-1}^{n}$ を導入しており， この細分化が次数と Integral Property の併用利用に寄与する .

Division Property は以下に示す単純な伝搬特性ルールを持つ

(注5)：もし $\mathbb{X}$ の全ての值が同偶数回出現するならば排他的論理和は 0 になる . 方もし $\mathbb{X}$ の全ての值が同奇数回出現するならば排他的論理和は 1 になる. 本稿にお ける $\mathcal{A}$ の定義は各値が同数回出現する多重集合であるため, X が $\mathcal{A}$ を持つという 条件のみでは排他的論理和が 0 になるか 1 になるかは不定となる．
命題 1 (Division Property の伝搬特性). $s$ を次数の上界が $d$ である $n$ ビット入力 $n$ ビット出力な非線形関数とする. $\mathbb{X}$ は 各要素が $n$ ビット值をとる非線形関数の入力集合であり， $\mathcal{D}_{k}^{n}$ を満足する. $\mathbb{Y}$ は非線形関数の出力集合であり各要素は全ての $x \in \mathbb{X}$ に対して $s(x)$ で計算される.このとき $\mathbb{Y} は \mathcal{D}_{\left\lceil\frac{k}{d}\right\rceil}^{m}$ を満

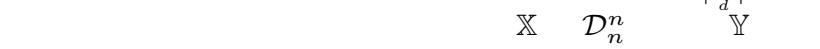
た $\mathcal{D}_{n}^{n}$ を満足する.

実際にどのように Division Property の伝搬を MISTY1に 適用するかは，更に複雑な評価が必要になる．したがって詳細 は CRYPTO 2015 の論文を参照されたい(8).

\section{2. 4 MISTY1 の解読}

従来知られていた最も強力な特性は 4 段 44 階 Integral 特性 であり，MISTY1 は 8 段であるため全体の半分を覆う特性だっ た ここの 4 段 Integral 特性に鍵回復を付加することで，7段まで 解析されていた ${ }^{(60)}$. 前節で示したように, Division Property を用いることで階数が大きくても正確な Integral 特性を導出で きるようになった。弚の結果，6段 63 階 Integral 特性 (图 9) が新たに発見され，新しい Integral 特性は従来の Integral 特性 と比較すると 2 段改良されている.MISTY1 は 8 段であるた め, 鍵回復は比較的容易に付加でき, 最終的に 8 段の仕樣段数 の解読が可能になった .

CRYPTO 2015 の Rump Session にて , MISTY1に対する 更なる改良攻撃手法が Bar-On によって示された ${ }^{(62)}$.これは Division Property を用いて発見された Integral 特性を利用 し，更に鍵回復部分を最適化した攻撃法である。結果，現在の

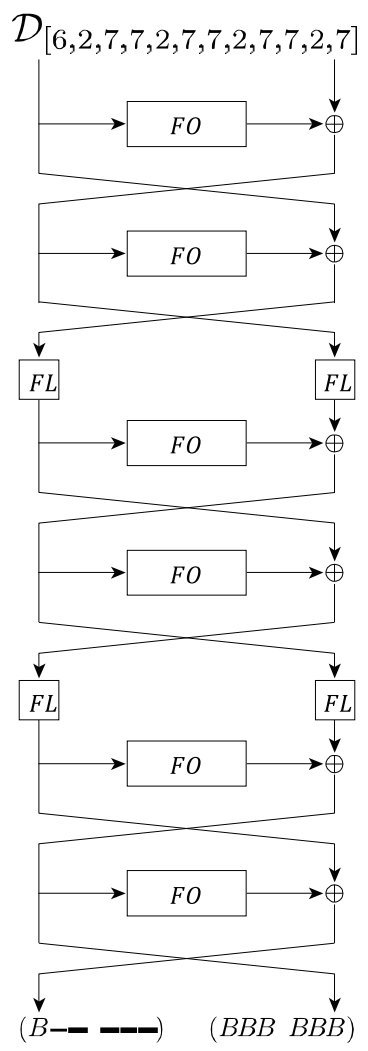

図 9 新しく発見された MISTY1の Integral 特性 


\section{MISTY1 の安全性レベルは $2^{70}$ 程度まで低下している．}

\section{3 Division Property は更に発展するのか?}

筆者は Division Property に関して二つの方向性を持って発 展していくことを期待する .

一つは新しい政撃手法の一つとしての応用展開である . 既に Zhang らは一般化 Feistel 構造への応用と軽量暗号 TWINE 及び LBlock ${ }^{(33)}$ への応用を示している ${ }^{(63)}$. Division Property を用いた解析では, 暗号構造をどのように表現して解析するか が非常に重要となる．適切な表現法は攻撃対象である暗号ごと に樣々であり，不適切な表現は Division Property の伝搬評価 を不可能にすることもあれば，発見できる Integral 特性の正確 さが非常に悪いものとなることもある. 今後 , これらを適用暗 号ごとに一つ一つ検証・検討・適用していく必要がある．

もう一つの方向性は理論としての拡張である . Division Propertyの提案者である筆者自身も FSE2016でBit-Based Division Property と呼ばれる新しい派生型を提案した ${ }^{(64)}$. また , 金子 は Division Property と Reed-Muller 符号の関係性を示してい $~^{(61)}$. Division Property の周辺に位置する理論研究も今後発 展すると期待する .

\section{6. おわりに}

本稿では共通鍵暗号の歴史を整理するとともに，MISTY1 を 理論解読する際に利用された新技術『Division Property』を概 観した .ブロック暗号解析は前世紀末に非常に盛んに取り組ま れた研究分野である. Integral 攻撃をはじめ多くの攻撃法が当 時提案されたにもかかわらず，これらは著名な暗号を解読するに 至らなかった .これは差分攻撃や線形攻撃と比較して, 新しい政 撃法に関する暗号学者の知識が依然として不足しているためで あると感じる . 今回 , Integral 攻撃に関して , 弚の本来の性能を 大幅に引き出す技術が新たに開発され，結果として著名暗号の 一角である MISTY1 が解読された．今後，Division Property の更なる応用を期待するとともに， Integral 攻撃以外の攻撃に 関しても弚の本来の性能を引き出す技術が提案されていくこと を期待する .

\section{謝 辞}

本稿を執筆するに際し , 多くの助言を頂いた三菱電機の松井 充氏に感謝致します．

(1) National Bureau of Standards, "Data Encryption Standard (DES)," Federal Information Processing Standards Publication 46, 1977.

(2) E. Biham and A. Shamir, "Differential cryptanalysis of DES-like cryptosystems," CRYPTO, A. Menezes and S.A. Vanstone, eds., LNCS, vol.537, pp.2-21, Springer, 1990.

(3) M. Matsui, "Linear cryptanalysis method for DES cipher," EUROCRYPT, T. Helleseth, ed., LNCS, vol.765, pp.386-397, Springer, 1993.

(4) E. Biham and A. Shamir, "Differential cryptanalysis of the full 16-round DES," CRYPTO, E.F. Brickell, ed., LNCS, vol.740, pp.487-496, Springer, 1992.

(5) K. Nyberg and L.R. Knudsen, "Provable security against a differential attack," J. Cryptol., vol.8, no.1, pp.27-37, 1995.

(6) M. Matsui, "New structure of block ciphers with provable security against differential and linear cryptanalysis," FSE, D. Gollmann, ed., LNCS, vol.1039, pp.205218, Springer, 1996.

(7) M. Matsui, "New block encryption algorithm MISTY," FSE, E. Biham, ed., LNCS, vol.1267, pp.54-68, Springer, 1997.

(8) Y. Todo, "Integral cryptanalysis on full MISTY1," CRYPTO Part I, R. Gennaro and M. Robshaw, eds., LNCS, vol.9215, pp.413-432, Springer, 2015.

(9) L.R. Knudsen and D. Wagner, "Integral cryptanalysis," FSE, J. Daemen and V. Rijmen, eds., LNCS, vol.2365, pp.112-127, Springer, 2002.

(10) Y. Todo, "Structural evaluation by generalized integral property," EUROCRYPT Part I, E. Oswald and M. Fischlin, eds., LNCS, vol.9056, pp.287-314, Springer, 2015.

(11) E. Biham, "New types of cryptanalytic attacks using related keys (extended abstract)," EUROCRYPT, T. Helleseth, ed., LNCS, vol.765, pp.398-409, Springer, 1993.

(12) L.R. Knudsen and V. Rijmen, "Known-key distinguishers for some block ciphers," ASIACRYPT, K. Kurosawa, ed., LNCS, vol.4833, pp.315-324, Springer, 2007.

(13) CRYPTREC, "Specifications of e-government recommended ciphers," available at http://www.cryptrec.go. jp/english/method.html, 2013.

(14) ISO/IEC, "JTC1: ISO/IEC 18033: Security techniques - encryption algorithms - part 3: Block ciphers," 2005.

(15) NESSIE, "New european schemes for signatures, integrity, and encryption," available at https://www. cosic.esat.kuleuven.be/nessie/, 2004.

(16) H. Ohta and M. Matsui, "A description of the MISTY1 encryption algorithm," available at https://tools. ietf.org/html/rfc2994, 2000.

(17) A. Shimizu and S. Miyaguchi, "Fast data encipherment algorithm FEAL," EUROCRYPT, D. Chaum and W.L. Price, eds., LNCS, vol.304, pp.267-278, Springer, 1987.

(18) E. Biham and A. Shamir, "Differential cryptanalysis of Feal and N-Hash," EUROCRYPT, D.W. Davies, ed., LNCS, vol.547, pp.1-16, Springer, 1991.

(19) M. Matsui and A. Yamagishi, "A new method for known plaintext attack of FEAL cipher," EUROCRYPT, R.A. Rueppel, ed., LNCS, vol.658, pp.81-91, Springer, 1992.

(20) U.S. Department of Commerce/National Institute of Standards and Technology, "Specification for the Advanced Encryption Standard (AES)," Federal Information Processing Standards Publication 197, 2001.

(21) J. Daemen and V. Rijmen, The Design of Rijndael: AES - The Advanced Encryption Standard, Information Security and Cryptography, Springer, 2002.

(22) X. Lai, "Higher order derivatives and differential cryptanalysis," Communications and Cryptography, The Springer International Series in Engineering and Computer Science, vol.276, pp.227-233, 1994.

(23) E. Biham, A. Biryukov, and A. Shamir, "Cryptanalysis of Skipjack reduced to 31 rounds using impossible differentials," EUROCRYPT, J. Stern, ed., LNCS, vol.1592, pp.12-23, Springer, 1999.

(24) A. Bogdanov and V. Rijmen, "Linear hulls with correlation zero and linear cryptanalysis of block ciphers," Des. Codes Cryptogr., vol.70, no.3, pp.369-383, 2014.

(25) P. Rogaway, M. Bellare, J. Black, and T. Krovetz, "OCB: a block-cipher mode of operation for efficient authenticated encryption," ACM CCS, M.K. Reiter and 
P. Samarati, eds., pp.196-205, ACM, 2001.

(26) D.A. McGrew and J. Viega, "The security and performance of the galois/counter mode (GCM) of operation," INDOCRYPT, A. Canteaut and K. Viswanathan, eds., LNCS, vol.3348, pp.343-355, Springer, 2004.

(27) 森井昌克 , 寺村亮一 , “ストリーム暗号の現状と課題,”信学 FR 誌, vol.2 , no.3 , pp.66-75 , Jan. 2009

(28) X. Wang, D. Feng, X. Lai, and H. Yu, "Collisions for hash functions MD4, MD5, HAVAL-128 and RIPEMD," 2004, Rump Session at CRYPTO 2004. https://eprint.iacr.org/2004/199.pdf

(29) 安田 幹, 佐々木 悠, “暗号学的ハッシュ関数一安全神話の崩 壊とあらたなる挑戦”, 信学 FR 誌, vol.4, no.1, pp.57-67 2010

(30) A. Bogdanov, L.R. Knudsen, G. Leander, C. Paar, A. Poschmann, M.J.B. Robshaw, Y. Seurin, and C. Vikkelsoe, "PRESENT: an ultra-lightweight block cipher," CHES, P. Paillier and I. Verbauwhede, eds., LNCS vol.4727, pp.450-466, Springer, 2007.

(31) J. Guo, T. Peyrin, A. Poschmann, and M.J.B. Robshaw, "The LED block cipher," CHES, B. Preneel and T. Takagi, eds., LNCS, vol.6917, pp.326-341, Springer, 2011.

(32) K. Shibutani, T. Isobe, H. Hiwatari, A. Mitsuda, T. Akishita, and T. Shirai, "Piccolo: An ultra-lightweight blockcipher," CHES, B. Preneel and T. Takagi, eds., LNCS, vol.6917, pp.342-357, Springer, 2011.

(33) W. Wu and L. Zhang, "LBlock: A lightweight block cipher," ACNS, J. Lopez and G. Tsudik, eds., LNCS, vol.6715, pp.327-344, Springer, 2011.

(34) T. Suzaki, K. Minematsu, S. Morioka, and E. Kobayashi, "TWINE : A lightweight block cipher for multiple platforms," SAC, L.R. Knudsen and H. Wu, eds., LNCS, vol.7707, pp.339-354, Springer, 2012.

(35) R. Beaulieu, D. Shors, J. Smith, S. TreatmanClark, B. Weeks, and L. Wingers, "The SIMON and SPECK families of lightweight block ciphers," IACR Cryptology ePrint Archive, vol.2013, p.404, 2013, http://eprint.iacr.org/2013/404

(36) E. Andreeva, A. Bogdanov, A. Luykx, B. Mennink, E. Tischhauser, and K. Yasuda, "Parallelizable and authenticated online ciphers," ASIACRYPT Part I, K. Sako and P. Sarkar, eds., LNCS, vol.8269, pp.424-443, Springer, 2013.

(37) T. Iwata, K. Minematsu, J. Guo, and S. Morioka, "CLOC: authenticated encryption for short input," FSE, C. Cid and C. Rechberger, eds., LNCS, vol.8540, pp.149-167, Springer, 2014, Submission to CAESAR competition.

(38) Y. Sasaki, Y. Todo, K. Aoki, Y. Naito, T. Sugawara, Y. Murakami, M. Matsui, and S. Hirose, "Minalpher v1," 2014, Submission to CAESAR competition.

(39) E. Andreeva, B. Bilgin, A. Bogdanov, A. Luykx, F. Mendel, B. Mennink, N. Mouha, Q. Wang, and K. Yasuda, "PRIMATEs v1.02," 2014, Submission to CAESAR competition.

(40) V.T. Hoang, T. Krovetz, and P. Rogaway, "Robust authenticated-encryption AEZ and the problem that it solves," EUROCRYPT Part I, E. Oswald and M. Fischlin, eds., LNCS, vol.9056, pp.15-44, Springer, 2015.

(41) "CAESAR: Competition for authenticated encryption: Security, applicability, and robustness," 2014, https: //competitions.cr.yp.to/caesar.html

(42) J. Daemen, L.R. Knudsen, and V. Rijmen, "The block cipher Square," FSE, E. Biham, ed., LNCS, vol.1267, pp.149-165, Springer, 1997.

(43) P.S.L.M. Barreto, V. Rijmen, J.N. Jr., B. Preneel, J. Vandewalle, and H.Y. Kim, "Improved SQUARE attacks against reduced-round HIEROCRYPT," FSE, M. Matsui, ed., LNCS, vol.2355, pp.165-173, Springer, 2001.

(44) K. Hwang, W. Lee, S. Lee, S. Lee, and J. Lim, "Sat- uration attacks on reduced round Skipjack," FSE, J. Daemen and V. Rijmen, eds., LNCS, vol.2365, pp.100111, Springer, 2002.

(45) Y. Yeom, S. Park, and I. Kim, "On the security of CAMELLIA against the Square attack," FSE, J. Daemen and V. Rijmen, eds., LNCS, vol.2365, pp.89-99, Springer, 2002

(46) S. Lucks, "The saturation attack - A bait for Twofish," FSE, M. Matsui, ed., LNCS, vol.2355, pp.1-15, Springer, 2001.

(47) A. Biryukov and A. Shamir, "Structural cryptanalysis of SASAS," EUROCRYPT, B. Pfitzmann, ed., LNCS, vol.2045, pp.394-405, Springer, 2001.

(48) L.R. Knudsen, "Truncated and higher order differentials," FSE, B. Preneel, ed., LNCS, vol.1008, pp.196211, Springer, 1994.

(49) Y. Li, W. Wu, and L. Zhang, "Improved integral attacks on reduced-round CLEFIA block cipher," WISA, S. Jung and M. Yung, eds., LNCS, vol.7115, pp.28-39, Springer, 2011

(50) M.R. Z'aba, H. Raddum, M. Henricksen, and E. Dawson, "Bit-pattern based integral attack," FSE, K. Nyberg, ed., LNCS, vol.5086, pp.363-381, Springer, 2008.

(51) H. Tanaka, K. Hisamatsu, and T. Kaneko, "Strength of MISTY1 without FL function for higher order differential attack," AAECC-13, M.P.C. Fossorier, H. Imai, S. Lin, and A. Poli, eds., LNCS, vol.1719, pp.221-230, Springer, 1999.

(52) A. Canteaut and M. Videau, "Degree of composition of highly nonlinear functions and applications to higher order differential cryptanalysis," EUROCRYPT, L.R. Knudsen, ed., LNCS, vol.2332, pp.518-533, Springer, 2002.

(53) J. Daemen, G. Bertoni, M. Peeters, and G.V. Assche, "The Keccak reference version 3.0," 2011.

(54) C.D. Cannière, H. Sato, and D. Watanabe, "Hash function Luffa - a SHA-3 candidate," 2008, Available at http://hitachi.com/rd/yrl/crypto/luffa/round1archive/ Luffa_Specification.pdf.

(55) C. Boura, A. Canteaut, and C.D. Cannière, "Higherorder differential properties of Keccak and Luffa," FSE, A. Joux, ed., LNCS, vol.6733, pp.252-269, Springer, 2011

(56) S. Babbage and L. Frisch, "On MISTY1 higher order differential cryptanalysis," ICISC, D. Won, ed., LNCS, vol.2015, pp.22-36, Springer, 2000.

(57) Y. Hatano, H. Tanaka, and T. Kaneko, "Optimization for the algebraic method and its application to an attack of MISTY1," IEICE Trans. Fundamentals, vol.E87-A, no.1, pp.18-27, Jan. 2004.

(58) Y. Tsunoo, T. Saito, M. Shigeri, and T. Kawabata, "Higher order differential attacks on reduced-round MISTY1," ICISC, P.J. Lee and J.H. Cheon, eds., LNCS, vol.5461, pp.415-431, Springer, 2008.

(59) Y. Tsunoo, T. Saito, T. Kawabata, and H. Nakagawa, "Finding higher order differentials of MISTY1," IEICE Trans. Fundamentals, vol.E95-A, no.6, pp.1049-1055, June 2012.

(60) A. Bar-On, "Improved higher-order differential attacks on MISTY1," FSE, G. Leander, ed., LNCS, vol.9054, pp.28-47, Springer, 2015

（61）金子敏信，“高階差分攻撃と積分攻撃”, 信学技報，ISEC201558 , pp.23-29, Dec. 2015 .

(62) A. Bar-On, "A $2^{70}$ attack on the full MISTY1," IACR Cryptology ePrint Archive, vol.2015, p.746, 2015. http://eprint.iacr.org/2015/746

(63) H. Zhang and W. Wu, "Structural evaluation for generalized Feistel structures and applications to LBlock and TWINE," INDOCRYPT, A. Biryukov and V. Goyal, eds., LNCS, vol.9462, pp.218-237, Springer, 2015.

(64) Y. Todo and M. Morii, "Bit-based division property and application to Simon family," IACR Cryptology 
ePrint Archive, vol.2016, p.285, 2016. (Accepted to FSE 2016). https://eprint.iacr.org/2016/285

(ISEC 研究会提案，平成 28 年 3 月 18 日受付)

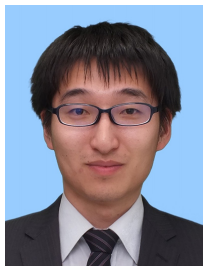

藤堂洋介 (学生員)

NTT セキュアプラットフォーム研究所研究員 . 修 $士$ (工学) . 国際暗号学会 (IACR) 会員 . 2010 神戶 大·工・電気電子卒. 2012 同大学院工学研究科電気 電子工学専攻了. 2012NTT 入社 . 2015 から神戶 大大学院工学研究科電気電子工学専攻博士後期課程 在学 . SCIS 論文賞 (2015), CRYPTO Best Paper Award(2015), CRYPTO Best Young Researcher Award(2015) 各受賞. 暗号理論の研究に従事. 